\title{
nature
}

14 April 2005 Volume 434 Issue no 7035

\section{Don't rely on Uncle Sam}

European regulators should pursue their own investigation into how the 'wrong' genetically modified corn was allowed on the market for years. Unfortunately, their US equivalents show little sign of rising to the challenge.

G iven widespread unease among the European public about genetically modified crops, you'd have expected the news that unapproved batches of transgenic seed containing a gene for antibiotic resistance had been shipped from the United States to Europe to have provoked a vigorous official response.

So far, however, reactions from Brussels have been equivocal. Markos Kyprianou, the European commissioner responsible for health and consumer protection, started strongly, declaring that he "deplores" the inadvertent release of unapproved seed in the European Union (EU). But since then, his spokesman has sent mixed messages. First, he simply expressed confidence in the ongoing US investigation into the incident; only later did he state that the European Commission is itself vigorously demanding more information from the company responsible about what happened.

The spokesman's second statement is appropriate; the first seems inadequate. This incident points to fundamental problems with the regulatory framework for agricultural biotechnology in the United States. And the response of the agencies involved gives little confidence that these problems are being seriously addressed.

The facts of the case are these: from 2001 until late last year, a US subsidiary of the Swiss firm Syngenta allowed American farmers to plant 15,000 hectares of corn, or maize, that had been modified with an unapproved version of a gene from the soil bacterium Bacillus thuringiensis that codes for an insecticidal protein (see Nature 434, $423 ; 2005)$. Small batches of the unapproved seed were also exported to Europe.

After Nature revealed this mistake, Syngenta claimed that there was no significant difference between the approved genetically modified corn, called $B t 11$, and the corn that had been inadvertently released, called Bt10. Only later did the company admit that $B t 10$ differs from $B t 11$ in that it contains an additional gene that confers resistance to the antibiotic ampicillin (see Nature 434, 548; 2005) a difference that most experts agree is of some significance.

\section{System error}

Some scientists are shocked that this oversight could have been allowed to persist for so long without detection. One might think that the US federal government, a long-standing champion of agricultural biotechnology, would be hopping mad about the mistake, and keen to get the facts out to satisfy sceptics around the world that it now has the situation firmly under control.

Think again. The US regulatory system divides responsibility between three different agencies, which have collectively failed to respond adequately to this incident. Under a framework introduced during the administration of President Ronald Reagan in the 1980s, the US Department of Agriculture (USDA), the Food and Drug Administration (FDA) and the Environmental Protection Agency (EPA) between them share responsibility for the approval and monitoring of genetically modified crops.

Broadly speaking, the USDA checks to see whether a transgene should be regarded as an agricultural 'pest'; the EPA considers the safety of proteins that can act as pesticides, such as the bacterial toxins expressed by $B t 10$ and $B t 11$; and the FDA is responsible for regulating other food safety aspects of transgenic crops.

The FDA has some justification in taking a back seat in the US investigation, noting that the toxin in Bt10, as a pesticide, falls outside its jurisdiction, and judging — quite reasonably — that the antibacterial-resistance gene in Bt10 does not represent a food safety problem.

The USDA, meanwhile, sees itself primarily as a promoter of US agriculture and related commercial interests - a self-image that has so far been reflected in its handling of this case. Its press office could be taking its line straight from Syngenta: "The system is working," a departmental spokesman said late last month of a process that has taken four years to unearth the cultivation of an unapproved crop. Using the time-honoured technique for burying uncomfortable information, the USDA chose to release news of its decision to fine Syngenta $\$ 375,000$ for its error on a Friday afternoon.

\section{Root cause}

That leaves the onus on the EPA to investigate the matter. In theory, it has the technical expertise and the legislative authority that it needs to function effectively. But in practice, the EPA's efforts in regulating transgenic crops are mostly devoted to premarketing approvals. According to well-informed critics, the agency has few resources to devote to the $B t 10$ investigation. This does little to dispel the message of a story carried on 23 March by the satirical website The Onion (www.theonion.com), which suggested that the EPA had announced that it would henceforth be known as The Agency. "We're not really 'environmental' anymore, and we certainly aren't 'protecting' anything," read a quote mischievously attributed to an agency official.

Given the state of the US investigation, the European Commission should establish the relevant facts to its own satisfaction. Syngenta, after all, is a European company - albeit one with headquarters in Switzerland, a non-EU state not known for the transparency of its corporate sector. The company should be forced to reveal how Bt10 got on to the market in the first place, and why it then took four years to discover the mistake.

So far, we've heard nothing on the former, and Syngenta has attributed the belated discovery of its inadvertent release of Bt10 to progress in the technology that it uses to monitor seeds. If true, this explanation will come as news to anyone who had assumed that the agricultural-biotechnology industry had known from the start what transgenes it was putting into its seeds. If the discovery was simply a matter of happenstance, we can have little confidence that similar problems won't occur again.

Thankfully, on this occasion we're not dealing with a threat to public health. But the incident will further undermine public confidence. Covering up the circumstances of the current incident may in the short term make life more comfortable for Syngenta and for the regulators who were supposed to prevent the release of unapproved seed. But the long-term prospects for the application of plant genetics would be better served by firm regulation and a degree of candour that has so far been sadly lacking in the performance of the main players in this case. 